\title{
膀胱腫瘍に扣ける顕微鏡的血尿の意味
}

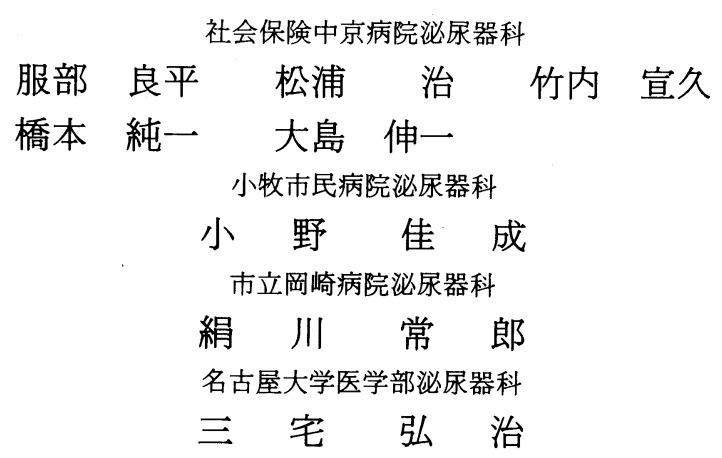

\section{CLINICAL IMPORTANCE OF MICROHEMATURIA AS AN INITIAL SIGN OF BLADDER TUMOR}

Ryohei Hattori, Osamu Matsuura, Norihisa Takeuchi, Junichi Hashimoto and Shinichi Ohshima

Department of Urology, Shakai Hoken Chukyo Hospital

Yoshinari Ono

Department of Urology, Komaki City Hospital

Tuneo Kinukawa

Department of Urology, Okazaki City Hospital

Koji Miyake

Department of Urology, Nagoya University School of Medicine

To investigate the role of microhematuria for the diagnosis of bladder tumor, the retrospective study of 156 patients with bladder tumor was done. Among the 156 cases, asymptomatic microhematuria was observed in 15 cases $(9.6 \%)$ as an initial sign of the disease. Acording to the process to the final diagnosis, these 15 cases were classified into 4 groups; the Group 1 comprised 4 patients who consulted the urologist just after health examination; the Group 2 comprised 6 patients who consulted the urologist by the introduction of the general practitioner; the Group 3 comprised 2 patients who disregarded the sign and consulted the urologist after the appearance of symptoms; the Group 4 comprised 3 patients whose general practitioner overlooked the sign and who consulted the urologist after the appearance of the symptoms. The mean duration between the initial sign and the final diagnosis of each group was 2, 2, 8 and 62 months, respectively. Three of the 5 patients $(60 \%)$ in groups 3 and 4 were treated by total cystectomy, while only 2 of the 10 patients $(20 \%)$ in groups 1 and 2 totally cystectomized. High grade tumor was observed more frequently in groups 3 and 4 than in groups 1 and 2 . Since the negative rate of urinary cytologic examinations of these 15 cases was $33.3 \%$, cystoscopic examination was necessary for screening of bladder tumor.

要旨：膀胼腫瘍例の初発症状として無症候性顕微鏡的血尿を主訴とした症例に注目して検討を行った。 対象は昭和 59 年 1 月より昭和 62 年 10 月までの 3 年10 カ月間に当科を受診した膀胖腫瘍 156 例で, 男性 132 例，女性 24 例，平均年齢は62歳であった。このうち無症候性䫓微鏡的血尿が初発症状であったものは15 例 (9.6\%) であった。当科を受診するまでの過程は次の 4 群に分類された。 I 群：検診にて尿潜血を指 摘後，すぐに当科を受診した例 ( 4 例)，II群：検診にて尿潜血を指摘され他医を受診後或は他医にて尿 潜血を指摘された後当科を受診した例 ( 6 例)，III群：検診にて尿潜血を指摘されたが放置し症状が出現 したため当科を受診した例 ( 2 例)，IV群：他医にて尿潜血を放置され症状が出現したため当科を受診し 
た例 ( 3 例)，尿潜血を指摘後，診断までの平均期間はそれぞれ 2 力月， 2 力月， 8 力月， 62 力月であっ た.治療として膀胱全摘出術を要したのは I, II 群では10例中 2 例(20\%), III, IV群では 5 例中 3 例(60\%) であり, III, IV群で多かった。 I, II 群では $\mathrm{G}_{2}$ 以上の high grade が 4 例 $(40 \%)$ にみられたのに対し， III，IV群では 5 例中 4 例 $(80 \%)$ が $\mathrm{G}_{2}$ であり，III，IV群で腫瘍の grade が高かった。これら15例の初診 時の尿細胞診では 5 例 $(33.3 \%)$ 陰性であり, 膀腅腫瘍のスクリーニング検査として膀胱鏡検査が必要 と考党られた。

\section{緒言}

血尿は尿路悪性腫瘍の症状として重要な意味を持っ ているが，顕微鏡的血尿，特に無症候性顕微鏡的血尿 の意味については十分な検討がなされているとはいえ ない，私共は尿路系悪性腫瘍例での無症候性顕微鏡的 血尿に注目し検討したところ $7 \%$ の症例に初発症状と 乙て無症候性顕微鏡的血尿を認め，無症候性顕微鏡的 血尿が尿路の悪性腫瘍を考劣る上で無視し得ないこと を報告した ${ }^{11}$ ：今回はこれらの悪性腫瘍例のらちもっ とも頻度の高かった膀胱腫瘍例と無症候性顕微鏡的血 尿との関係について検討したので報告する。

\section{対象}

対象は昭和 59 年 1 月より昭和 62 年 10 月までの 3 年 10 カ月間に当科を受診した膀胱腫瘍156例である，男性 132例，女性24例で平均年齢はそれぞれ63歳，62歳で あった。

\section{方 法}

膀脱腫瘍例の初発症状を肉眼的或は顕微鏡的血尿の 有無, 他の症状の有無により分類し, 初発症状が無症 候性顕微鏡的血尿である症例について

(1) 泌尿器科専門医（当科）を受診するまでの過程

(2) 診断を受けるまでの期間

(3) 尿細胞診と顕微鏡的血尿との関係

(4) 治療方法

(5) 腫湯の grade について検討した。

\section{結 果}

156例の初発症状を肉眼的或は顕微鏡的血尿の有無, 他の症状の有無により分類した（図 1). 初発症状とし て肉眼的血尿を認めた例が102例 (65.3\%)，顕微鏡的 血尿を認めた例が33例（21.2\%）であり，両者を合わ せると $86.5 \%$ に血尿を認めた。このうち無症候性顕微 鏡的血尿が初発症状であったものは図中黒塗で示した が，156例中15例 (9.6\%) であった。

これら15例は男性14例女性 1 例であった，年龄は 43 歳から78歳であり平均年齢は64歳であった。顕微鏡的 血尿の発見動機は検診にて指摘されたものが 8 例, 他
図 1 初発症状としての血尿の頻度

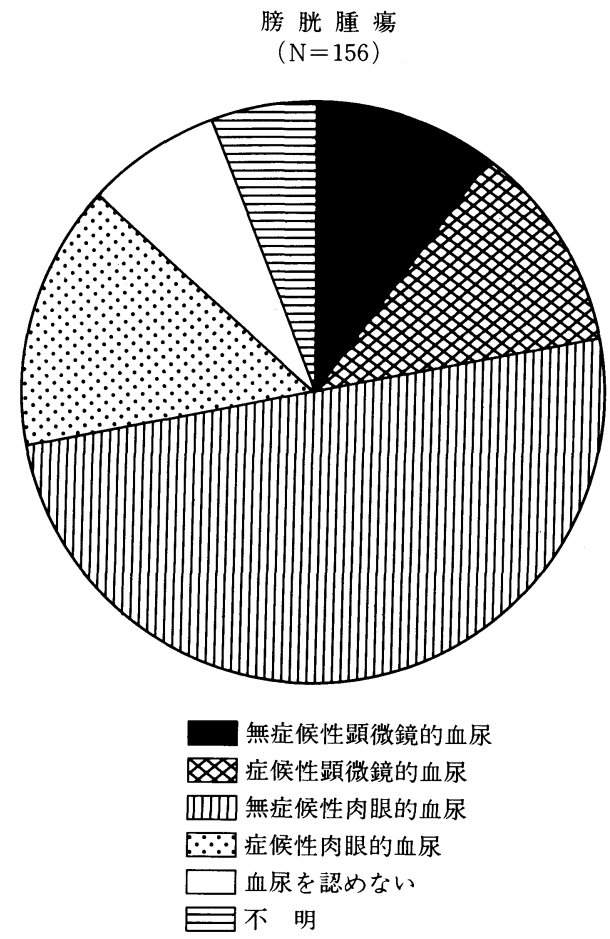

科治療中偶然指摘されたものが 7 例であった，顕微鏡 的血尿を指摘されてから膀胱腫瘍の診断を受けるまで の期間は 4 日から 10 年，平均 15 力月であり，治療法と しては TUR が10例に，膀胼全摘出術が 5 例に施行さ れた（表 1 ).

図 2 に各症例の尿潜血を指摘されてから診断にいた るまでの経過を示す.症例 9 は女性で, 他は男性であっ た。当科を受診するまでの過程は様々であり，次の 4 群に分類された(表 2)．I 群：検診にて尿潜血を指摘 後，すぐに当科を受診した例，II群：検診にて尿潜血 を指摘され他医を受診後或は他医にて尿潜血を指摘さ れた後当科を受診した例，III群：検診にて尿潜血を指 摘されたが放置し症状が出現したため当科を受診した 例，IV群：検診にて尿潜血を指摘され他医を受診する 
表 1 初発症状が無症候性顕微鏡的血尿であった症例

\begin{tabular}{|c|c|}
\hline 例 数 & 15例（男性14例 女性 1 例） \\
\hline 平均年齢 & $64 \pm 13$ 歳（43～78歳） \\
\hline $\begin{array}{l}\text { 膀胱腫瘍例に } \\
\text { 対する割合 }\end{array}$ & $9.6 \%$ \\
\hline 発見動機 & $\begin{array}{l}\text { 検診にて指摘 } \\
\text { 他科治療中例 } \\
\text { 然指摘：77 例 }\end{array}$ \\
\hline $\begin{array}{l}\text { 診断までの } \\
\text { 期 間 }\end{array}$ & $\begin{array}{l}\text { 平均 } 15 \text { 个月 } \\
(4 \text { 日 } 10 \text { 年 })\end{array}$ \\
\hline 治 療法 & $\begin{array}{l}\text { TUR } \\
\text { 膀脱全摘出術：10例 } \\
5 \text { 例 }\end{array}$ \\
\hline
\end{tabular}

表 2 当科への受診過程による分類

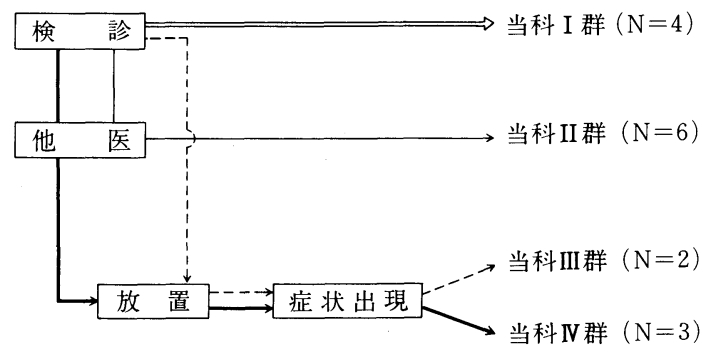

も診断がつかず，或は他医にて尿潜血を指摘されたが 放置され症状が出現したため当科を受診した例であ る。つまり I， II群は尿潜血を指摘された後放置せず に泌尿器科専門医を受診した例であり，III，IV群は尿 潜血を指摘されながら患者本人または一般医が放置し 症状出現後泌尿器科専門医を受診した例である. I 群 4 例II群 6 例，III群 2 例，IV群 3 例であった．診断に 至るまでの期間を各群間で比較してみると，尿潜血を 指摘されてから診断までの平均期間は I, II 群共 2 カ 月, III群 8 カ月, IV群 62 力月であった.

今回検討した15例の膀胼腫瘍の当科初診時の尿細胞 診で疑陽性（class 3）以上の結果がでたものは15例中 10例あった。当科初診時での尿細胞診の陽性率を各群 間で検討してみると（表 3 )，I I 群は 4 例共 low grade で尿細胞診が陰性であり，II群では high grade の症例 は初診時既に全例陽性であり, low grade 例では 2 例 中 1 例が陽性であった。III，IV群では全例疑陽性また は陽性であった。

早期に泌尿器科専門医を受診した I, II 群と症状出 現まで放置したIII, IV群で治療方法, 腫瘍の grade 比較検討した。膀胼全摘出術を要したのは I， II 群で は10例中 2 例(20\%)，III，IV群では 5 例中 3 例(60\%) であり，III，IV群で多かった．膀胱全摘出術を行った
図 2 治療までの経過

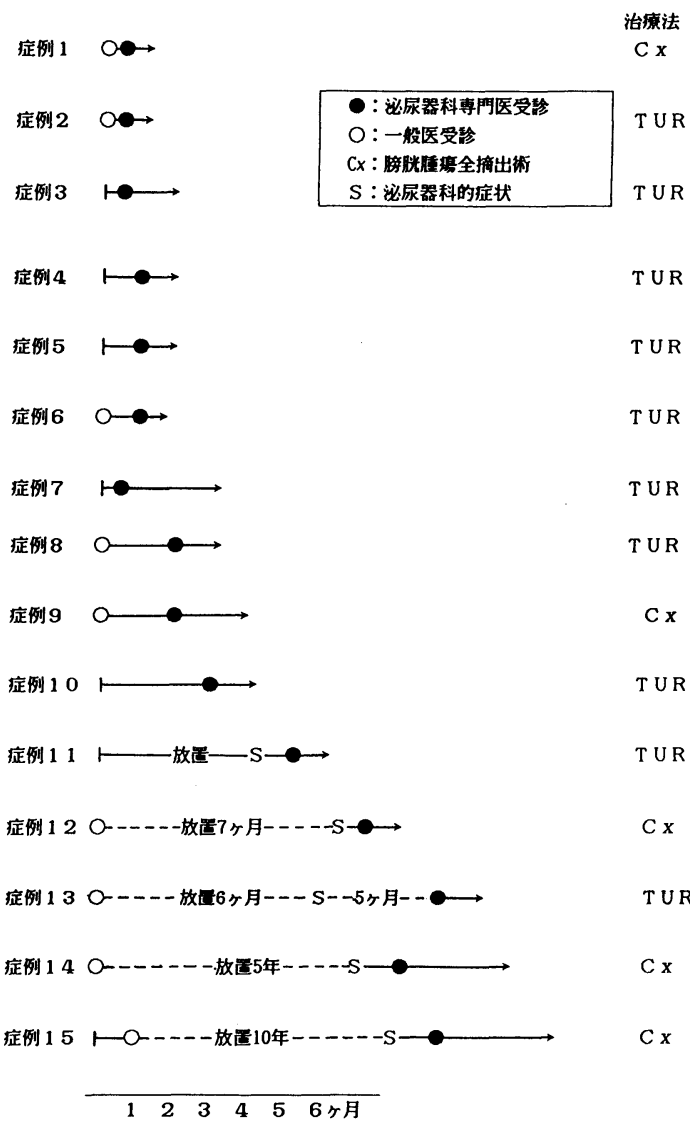

表 3 当科初診時尿細胞診と腫場の悪性度

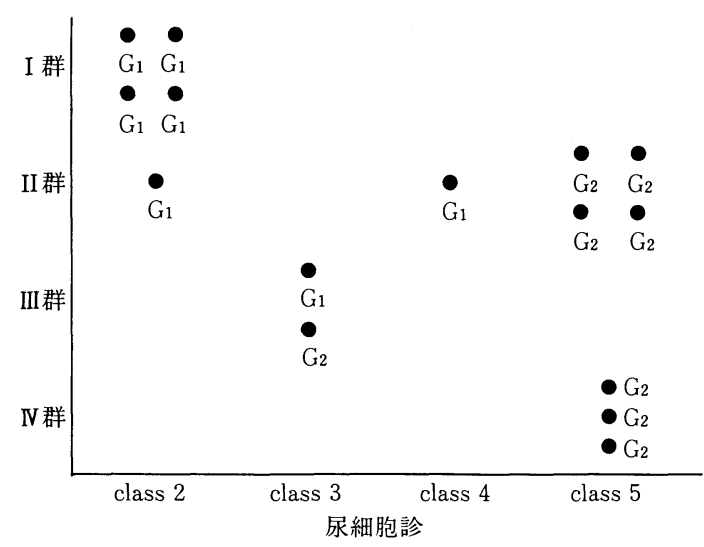

5 例のうち I, II 群の 2 例は PT2 と PT3A であり III, IV群の 3 例は PT1, PT2, PT3A であった.

次に腫瘍の grade の比較では, I, II 群では $\mathrm{G}_{2}$ 以上 の high grade が 4 例 (40\%)にみられたのに対し, III, 
IV群では 5 例中 4 例 $(80 \%)$ が $\mathrm{G}_{2}$ であり，III，IV群で 腫瘍の grade が高かった。

\section{考 察}

膀胀腫痬の診断に際して血尿, 特に肉眼的血尿は最 も重要な症状の 1 つである。従来の報告によれば，膀 胱腫瘍例で初発症状として肉眼的血尿を認めた例は $60 \%$ から $90 \%{ }^{2) ~ 9)}$ であり，私共の今回の検討でも肉眼 的血尿を認めた例は156例中103例（65.3\%）であり諸 家の報告々一致している。一方, 膀胖腫場の初発症状 としての顕徽鏡的血尿について言及した報告は少なく 吉田 ${ }^{3)}$ が163例の膀脱腫瘍例のうち検診にて顕徽鏡的 血尿または膿尿を指摘された例が 5 例 (3.1\%) あった と指摘しているにすぎない，今回の私共の検討では初 発症状として顕微鏡的血尿を認めた膀胱腫瘍例は156 例中33例（21.2\%）にみられ決して少なくない。また このらち何らかの症状を有していた症例を除いた無症 候性顕徽鏡的血尿を初発症状としていた膀胖腫瘍例は 156例中15例（9.6\%）にみられており，無症候性の顕 微鏡的血尿も決して無視し得ない重要な症状と認識す べきと思われる。

今回の私共の検討では膀脂腫瘍例の約 1 割が無症候 性顕微鏡的血尿を初発症状として招り予想以上の頻度 であった。これは今回私共が顕微鏡的血尿といらこと を特に意識して集計したことに加え，検診の普及やテ ステープの一般化により尿検査を受ける機会が増加し ていることも大きな要因であろう。保健所に拈ける集 団成人病健康診断受診者は昭和 45 年には $2,012,966$ 人 であったのが昭和 62 年には $4,161,329$ 人と增加し ${ }^{10)}$, 労 働省の定期健康診断実施結果によっても受診者数は昭 和 40 年は $9,370,497$ 人であったのが昭和 61 年 は $10,900,258$ 人と増加している ${ }^{11}$ 。 また昭和 47 年に制定 された労働安全衛生法に於て検尿が定期健康診断の項 目となって扬り，尿潜血を指摘される機会が増えてき ているのは確実である.

しかし尿潜血の陽性例に対する診療システムについ ては確立されているとは言えないのが現状であり，今 回私共が検討した15例中 5 例が尿潜血を指摘されてか ら泌尿器科専門医の診察をらけておらず泌尿器科的症 状が出現してから泌尿器科専門医を受診し，らち 3 例 は腫瘍の進行のため膀胱全摘出術が必要であったこと はこのことを強く実感させるものである。吉田 ${ }^{3}$ は膀 胱腫瘍例の集計で初発症状出現から泌尿器科受診まで の期間が 3 力月以内の症例は 3 力月以上の症例に比べ 非浸潤性腫瘍の割合が多かったと述べており私共の今
表 4 無症候性顕微鏡的血尿症例中膀胱腫場発見例

\begin{tabular}{c|c|c|c|c}
\hline 発 表 者 & 発表年 & 対 象 & 年 龃 & 膀胱腫瘍例 $(\%)$ \\
\hline 井 川 & 1982 & 350 例 & & 1 例 $(0.3 \%)$ \\
\hline 米 山 & 1983 & 145 例 & 平均64歳 & 1 例 $(0.7 \%)$ \\
\hline 村 上 & 1986 & 637 例 & 平均53歳 & 7 例 $(1.1 \%)$ \\
\hline 壽 美 & 1987 & 232 例 & 平均56歳 & 6 例 $(2.6 \%)$ \\
\hline 森 田 & 1987 & 315 例 & 平均49歳 & 6 例 $(1.9 \%)$ \\
\hline 自験例 & 1987 & 339 例 & 平均48歳 & 1 例 $(0.3 \%)$ \\
\hline
\end{tabular}

回の検討でも尿潜血を指摘されてからすぐに泌尿器科 専門医を受診した I, II 群では治療開始をでの期間が 短く, 治療方法もTURで済んでおり膀胼腫場例でも 他の腫瘍と同様に，早期発見早期治療が重要であるこ とを示している。

今回の検討では治療までの期間の長かったIII, IV群 で high grade の腫瘍が多かったが, 初発症状から治療 までの期間と腫瘍の grade との間に何らかの関係が あると結論づける根拠はない. Wallace ${ }^{24)}$ は膀朕腫痬 の grade と治療までの期間は関係がないと指摘して いる.

検診や，偶然発見される尿潜血陽性者から膀胼腫汮 の発見される割合は本邦では0.3 2.6\%であり ${ }^{12) ~ 17) ~}$ （表 4)，私共の retrospective な無症候性顕微鏡的血 尿患者339例を対象とした検討でも膀胱腫瘍 1 例 (0.3\%)が発見されているにすぎない、17).これらの報告 からは，無症候性顕微鏡的血尿を主訴とした患者から の膀胼腫瘍の発見率はけっして高くはない.このこと は, 今回の私共の検討結果と大きく異なる内容であっ た。この原因について私共は顕微鏡的血尿の発見され る動機が，検診やあるいは偶然にということが多く， 一般医はもちろん泌尿器科の専門医も, この取扱いに 苦虑しているのが実状で, 従って顕微鏡的血尿を発見 した後の検查の不統一，不十分なところにあるのでは ないかと考元た，膀胼腫瘍の診断は最終的には膀胱鏡 によるものが最も信頼性が高い，だが，患者に対する 苦痛などを考えれば他の非侵襲的な検査でこれに代わ るものがあれば，その方がよい，そこで膀脱鏡以外の 手段である尿細胞診や，超音波検査などによる検査が ぞれ程の信頼性を持っているかを検討してみた。まず 尿細胞診についてみてみる。

結果の項で述べた様に，顕微鏡的血尿の発見後早期 に受診した I, II群に比し, 初診までに長期間を要し たIII，IV群で有意に細胞診陽性率が高かった。尿細胞 
診について膀胀腫瘍との関係について検討された諸家 の報告によれば膀胖腫瘍に於ける尿細胞診の陽性率は 50\%から80\%であるといわれている ${ }^{18) 21)}$. 長田らは膀 胼腫瘍の尿細胞診陽性率は high grade $86.8 \%$ に対し low grade $48 \%$ であり, high stage $89.3 \%$ に対し low stage $48.2 \%$ と報告しており ${ }^{21)}$, low grade, low stage の膀胱腫瘍での尿細胞診の陽性率はそれ程高くはない ようであり，今回私共の顕微鏡的血尿を初発症状とし た膀脱腫瘍での陽性率は $53 \%$ であり，諸家の報告と一 致しているが，顕微鏡的血尿と細胞診の関係でみる限 りに扔いては，むしろ発見時から初診時までの期間の 長短に，より大きな意味があると考えられた。

膀胖腫湯の診断に際して超音波検査が侵襲がないこ とから注目されつつあるが，麦谷等は 16,377 人のスク リーニング検査で無症候性の膀胼腫瘍を 6 例発見し, 超音波検查の有用性を示したが22), Itzachek 等は71例 の膀羘腫瘍例中27例（38\%）は超音波検査にて発見さ れず, 茎が $5 \mathrm{~mm}$ 以下或は部位が膀胱頝部, 頂部にある 膀胱腫湯は発見が難しいと述べている ${ }^{23)}$.

これらを総合的に考劣ると膀胀腫場のスクリーニン グ検查として尿細胞診, 超音波検査は有用ではあるが false negative の可能性が常にしかも，かなり高頻度 にあり，従って膀胼腫瘍の診断のための膀脱鏡検査に 匹敵する方法は，現時点ではないものと判断せざるを 得ない，私共はこの観点に立ち昭和62年より無症候性 顕徽鏡的血尿症例に対しては独自の方法を考兄，それ に従って検査を進めるようにし特に 40 歳以上の症例で は全例膀胱鏡を施行している.40歳以上と決めたのは, 膀胱腫場の発見例がすべて40歳以上であったことによ る ${ }^{17)}$. まだ未発表であるが尿潜血症例に対する系統的 なスクリーニング検査により膀胖腫瘍の発見される割 合が増加しており今後とも40歳以上の無症候性顕微鏡 的血尿症例に対しては膀胼鏡検査を行っていく予定で ある。

\section{結 語}

1. 膀胀腫瘍 156 例中初発症状が無症候性䫓徽鏡的血 尿の症例は15例 (9.6\%) であった。

2. 尿潜血を指摘されてから診断までの期間を

I 群：検診にて尿潜血を指摘され当科を受診した例

II群：検診にて尿潜血を指摘され他医を受診後, 或 は他医にて尿潜血を指摘された後当科を受診した例

III群：検診にて尿潜血を指摘されたが放置し症状が 出現したため当科を受診した例

IV群：検診にて尿潜血を指摘され他医を受診, 或は
他医にて尿潜血を指摘されたが放置され症状が出現し たため当科を受診した例

に分類し検討した結果, I, II 群平均 2 力月, III群平 均 8 力月, IV群平均 62 力月であった。

3. 15例中尿細胞診は10例が疑陽性以上であり, I 群 では全例陰性, II 群では陰性は 1 例, III, IV群では 5 例全例疑陽性以上で， $5 ち 3$ 例は class 5 の陽性例で あった。

4. 膀羘全摘出術を行なったのは I, II 群では10例中 2 例 $(20 \%)$ であったのに対し，III，IV群では 5 例中 3 例（60\%）であった。

5. III, IV群で high grade の例が I, II 群に比し多 くみられた。

\section{文献}

1）服部良平, 絹川常郎, 松浦 治, 竹内宣久, 長谷川 総一郎, 大島伸一，小野佳成，三宅弘治：尿路悪性 腫䁑に扔ける顕微鏡的血尿の意味. 日泌尿会誌, 79, 1393-1398, 1988.

2）加藤篤二, 石部知行, 田辺泰民, 竹中生昌, 福重 満, 白石恒雄, 平川十春, 数田 稔, 藤本洋治, 溝 口 勝, 嶋田孝宏, 田中広見, 小川昌彦, 暒尾克彦, 伊藤順勉：膀胼腫場の手術成績。泌尿紀要, 12 , 333-340, 1966.

3）吉田 修: 膀胱癌に関する研究. 第II 編. 膀胱癌患 者244例の臨床的観察（浸潤度および遠隔成績を中 心として)。泌尿紀要，12，1261-1280，1966.

4）岡島英五郎, 平松 㑆, 本宮善恢, 入矢一之, 林威 三雄, 石川昌義：膀胖腫煌に関する臨床的研究. 日 泌尿会誌，61，783-804，1970。

5）黑沢昌也, 鈴木騏一, 佐々木篤生, 加藤正和：膀胱 腫場 の臨床統計的観察. 日泌尿会誌, 63, 1001-1006, 1972.

6）伊藤泰二, 森 義則, 永田 肇, 清原久和：膀胖腫 瘍270例の治療成績：TURを中心として。泌尿紀 要, 72, 33-41, 1976.

7）西尾正一, 柏原 昇, 川喜多順二, 西島高明, 前田 勉, 松村俊宏, 佐々木進, 船井勝七, 中西純造, 早 原信行, 辻田正昭, 岸本武利, 前川正信 : 膀腅癌の 臨床統計学的観察. 泌尿紀要, 22, 489-495, 1976.

8）高士宗久, 村瀬達良, 三宅弘治, 三矢英輔：膀脱腫 瘍の統計学的研究一臨床的 - 病理学的因子と予後 との関係一. 日泌尿会誌, 76, 1323-1335, 1985.

9）小幡浩治, 山崎義久, 村瀬達良, 上田公介, 栗山 学, 鈴木和雄, 吉田和彦, 大島伸一, 藤田民夫, 浅 野晴好, 鈴木茂章, 斉藤 薰, 磯貝和俊, 成瀬克邦： 東海地方会泌尿器腫崵登録による 4 年間の膀胱腫 瘍統計。日泌尿会誌, 77, 988-994, 1986.

10）昭和63年国民衛生の動向．p. 112.

11）昭和63年国民衛生の動向. p. 352 . 
12）壽美周平, 國保昌紀, 石橋克夫, 山内民夫, 熟塚 誠, 川合恒雄, 桜井賢二：無症候性顕微鏡的血尿 232例の臨床的検討. 臨泌, 41, 143-148, 1987.

13）村上信乃, 五十嵐辰男, 山西友典, 始関吉生：無症 候性血尿の臨床的検討. 特に検診にて認められた 血尿について. 日泌尿会誌, 77, 1078-1081, 1986.

14) 米山威久, 富田康敬: 顕微鏡的血尿と泌尿器科疾 患. 腎と透析, 15, 235-237, 1983.

15）井川幹雄, 相模浩二, 平山多秋：膀朕腫瘍の臨床統 計的観察. 西日泌尿, 44, 747-754, 1982.

16）森田博人, 武村 聡, 岡田清己, 岸本 孝: 無症候 性顕微鏡的血尿の臨床的検討. 西日泌尿, 49, $1121-1125,1982$.

17）服部良平, 絹川常郎, 松浦 治, 竹内宣久, 長谷川 総一郎, 大島伸一, 小野佳成：無症候性顕微鏡的血 尿の臨㦿的意義一第 I 報一。日泌尿会誌，78， 1054-1050, 1987.

18）坪井成美, 秋本成太, 矢崎恒忠, 由井康雄, 中島 均, 戸塚一彦, 川井 博：尿細胞診の臨床統計. 臨 泌, 33，469-474, 1979.

19）能登宏光, 根元良介, 加藤哲郎：尿細胞診の臨床的 意義. 臨泌, 35, 469-473, 1981.
20）根本真一, 石川 悟, 武島 任, 飯泉達夫, 内田克 紀, 矢崎恒忠, 根本良介, 林正健二, 加納勝利 : 尿 細胞診の臨床的検討一膀胱腫瘍を中心に一. 泌尿 紀要, 29, 1611-1615, 1983.

21）長田尚夫, 井上武夫, 山越昌成, 黒子幸一, 吉尾正 治, 黒田. 俊, 中野 勝, 浜尾 功, 大山 登: 尿 細胞診の検討, 第 2 報。特に class III, false positive, false negativeについて. 西日泌尿, 46, $541-547,1984$.

22）麦谷荘一, 鈴木俊秀, 田島 惇, 関口 浩, 金子佳 雄, 秋山敏一, 杉山 高, 阿曽佳郎：膀脂腫瘍早期 診断における経腹壁的超音波断層法の有用性につ いて。 日泌尿会誌，79，847-852，1988.

23) Itzchak, Y., Singer, D. and Fischelovitch, Y.: Ultrasonographic assessment of bladder tumors. I. Tumor detection. J. Urol., 126, 31-33, 1981.

24) Wallace, D.M. : The natural history and possible cause of bladder tumours. Ann. R. Coll. Surg. Engl., 18, 366-383, 1956.

（1989年11月15日受理） 